\title{
Short and Long Term Relationship between Economic Growth and Unemployment in Egypt: An Empirical Analysis
}

\author{
Fouzeia Mohmed Alhdiy \\ Faculty of Economics and Muamalat, Universiti Sains Islam Malaysia (USIM), Malaysia \\ Email: Fou77mohemad@yahoo.com
}

Fuadah Johari

Faculty of Economics and Muamalat, Universiti Sains Islam Malaysia (USIM), Malaysia

Email: fuadah@usim.edu.my

Siti Nurazira Mohd Daud

Faculty of Economics and Muamalat, Universiti Sains Islam Malaysia (USIM), Malaysia

Email: nurazira@usim.edu.my

Asma Abdul Rahman

Faculty of Languages and Major Studies, Faculty of Economics and Muamalat, Universiti Sains Islam Malaysia (USIM), Malaysia

Email: asma@usim.edu.my

\section{Doi:10.5901/mjss.2015.v6n4s3p454}

\section{Abstract}

This study aims to examine the relationship between growth and unemployment in Egypt between 2006 Q1 - 2013 Q2. The Dickey-Fuller (ADF) unit root test, the Johansen Co-integration test and the Standard Granger Causality test were applied to examine the relationship between unemployment and Gross Domestic Product (GDP). The results indicated there were no cointegration relationship between the variables of unemployment and GDP specifically implying there is no long-term relationship between the variables. However, in the short term, there is a direct causality relationship have been observed between the unemployment rate to economic growth.

Keywords: Economics Growth, Unemployment, EGYPT

\section{Introduction}

Unemployment has become one of the most serious challenges that threaten the economies of most developed and developing countries such as socio-economic problems; high rates of unemployment which signifies a deficiency in the labour market, deepening poverty incidence and spread of indecent standards of living Shorbaji (2009) and Kreishan (2011). On the other hand, there is a widely accepted view in economics that the growth rate of the GDP of an economy increases employment and reduces unemployment. This theoretical proposition relating to output and unemployment is generally known as "Okun's Law".

This phenomenon has attracted the attention of economists, not only because it has a robust empirical regularity but also because of its importance as a macroeconomic building block. When it is combined with the Phillips curve, it produces the aggregate supply curve. It has also implications for macroeconomic policy, particularly in determining the optimal or desirable growth rate Mossa (2008), Dahmani (2013). However, very few attempts to test this relationship have been conducted in developing countries and mainly in Arab countries. Therefore, the motivation of this study is to test the relationship between unemployment and Gross Domestic Product (GDP) rates in Egypt.

In Egypt, unemployment rates during the last period have been rising erratically, between periods of modest unemployment rate, such as those during 1990s, to a very high number of unemployed rates in the last few years. Table (1) displays unemployment rate and economic growth rates over the last decade. The unemployment rate in Egypt 
fluctuated from 9 percent and 12.7 percent respectively. Despite a slight decrease in 2008, unemployment rates have been relatively high in comparison with an average growth rate of 4.67 percent.

Table 1: Unemployment rate and economic growth in Egypt (2003-2012)

\begin{tabular}{|c|c|c|}
\hline Years & Unemployment rate (\%) & Economic growth rate (\%) \\
\hline 2003 & 10.4 & 3.2 \\
\hline 2004 & 10.7 & 4.1 \\
\hline 2005 & 11.2 & 4.5 \\
\hline 2006 & 10.6 & 6.8 \\
\hline 2007 & 8.9 & 7.1 \\
\hline 2008 & 8.7 & 7.2 \\
\hline 2009 & 9.4 & 4.7 \\
\hline 2010 & 9 & 5.1 \\
\hline 2011 & 12 & 1.8 \\
\hline 2012 & 12.7 & 2.2 \\
\hline Average & 10.36 & 4.67 \\
\hline
\end{tabular}

Source: W D I, World Development Indicators

During the period $2003-2012$, the predominant feature of unemployment is its high rates persistence. These figures reveal the gravity of the unemployment problem in Egypt. Thus, an investigation of the output relationship will permit analysts to conduct appropriate policies for the reduction of unemployment in the country.

\section{Analysis of Economic Growth and Unemployment in Egypt during the Last Two Decades}

The Egyptian economy is primarily based on revenues of tourism, oil and Suez Canal remittances from Egyptians and from foreign investments abroad. Therefore, the volume of economic growth is associated to the conditions that occur on these elements. Mahfouz (2009).

Based on Figure (1) below, it can be noted that the period between $1990-2011$, there are many fluctuations in real economic growth. This can be explained by the political and economic changes, whether locally or globally. In May 1991, Egypt signed "Economic Reform and Structural Program" (ERSP) with the International Monetary Fund (IMF) and International Bank for Reconstruction and Development to alleviate structural imbalances suffered by the Egyptian economy. During this period the economic growth rates rose from 1.1 percent in 1991 to 6.1 percent in 1999, offset by a decrease in the unemployment rate from the highest level of 11.3 percent in 1995 to 8.1 percent in 1999.

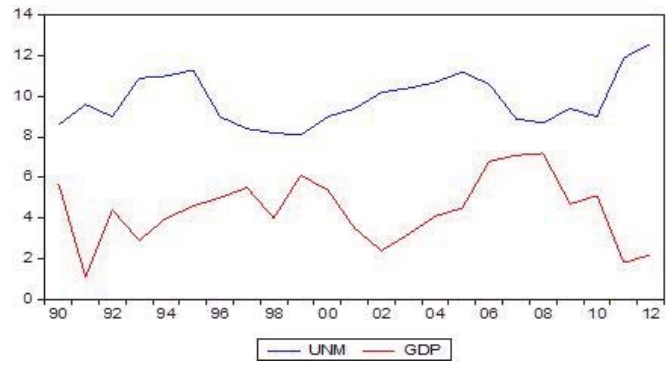

Figure 1: Unemployment Rates and Economic Growth, 1990- 2012

Source: W D I, World Development Indicators

However, by the end of the nineties, the Egyptian economy confronted a range of external shocks, which resulted in decline of Suez Canal revenues, remittances from workers abroad and the collapse of world oil prices. Mahrous (2005), this led to a significant decline in economic growth rates but an increase in unemployment rates during the period (20012005).This event eventually led to an increase in unemployment rates. In addition, the labour market in Egypt is 
witnessing an annual increase of 700 thousand new graduates due to the high rate of population growth Chloe (2010). However, the growth rates of the following years have helped to reduce unemployment from 11.2 percent in 2005 to 8.7 percent in 2008, with an average growth in GDP of 7.2 percent in 2008, which was the highest growth achieved during the study period.

The Egyptian economy is an open emerging economy, has been negatively affected by the global economic crisis, leading to a sharp deterioration in most economic indicators, particularly the shrinking export revenues and lower remittances and sharp decline and sudden share investments as a percentage of GDP from 15.1 percent in 2008 to 9.6 percent in 2009 Ministry of Investment, Egypt (2012), This resulted in a decline in the growth rate of annual GDP to 4.7 percent in 2009, but in spite of all that the Egyptian economic growth reached 5.1 percent in 2010. Then the Egyptian government announced a financial package of 15.5 percent in billion Egyptian pounds in order to stimulate aggregate demand and mitigate the impact of the crisis on the affected sectors, Chloe (2010). In the year 2011, many things happened in Egypt, which resulted in a change the political system. The drop of most of the economic performance indicators after the revolution was mainly impacted by a series of political obstacles and instability with the introduction to these indicators. The economic growth rate decreased to offset an increase of 1.8 percent in the unemployment rate to 12.4 percent in the fourth quarter of 2011. It was previously 9.1 percent in the first quarter of 2010, Al-Habees \& Abu Rumman (2012), the Ministry of Investment, Egypt (2012). In general it can be said that Egypt has experienced many political, social, economic, domestic and international changes that have had a significant impact on the stability of the national economy. This has led to a severe deterioration in economic conditions, particularly the decline in economic growth rates oscillating originally, which contributed to the slow operating growth and thus high unemployment. Thus, this study is aimed to investigate the relationship between unemployment and Gross Domestic Product rates (GDP) in the Egyptian economy.

The rest of this study consists of three sections. The first section briefly reviews some previous research studies on the relationship between GDP and unemployment, the second discusses research methodology used to analyse this relationship and research findings, while concluding remarks are offered in the last section.

\section{Literature Review}

In general, most of the studies especially in developed countries, confirm the relationship given by Okun (1962) to test the correlation between the product and the unemployment rate but the results is differ from one country to another and over the years as per the nature of economic growth achieved in particular State.( Revenge \&Beutalia; 1995, Lee ; 2000, Sogner \& Stiassny; 2002, Harris \& Silverstone ; 2001, Zagler ; 2003, Yerdelen ; 2011, Ivan \& Oleg; u.d).

However, a range of other studies showed lack or weakness of this relationship in developing countries in general and in the Arab world in particular, for example Al-Ghannam (2003) has performed an applied study to analyze the relationship between the rate of economic growth and employment in private enterprises of Saudi Arabia, by using the cointegration test and error correction model. The causality to Granger led to existence of a long-term balancing relationship between the employment rate and economic growth, and the existence of a causal relationship only in one-way from the rate of economic growth to employment and not vice versa.

In addition, Al-Eid \& Bahadi (2012) researched the possibility of the existence of this relationship in the Palestinian territories for the period 1996 - 2011, by using a simple regression model and annual data. The experimental results showed the existence of a weak inverse relationship between growth in GDP and the unemployment rate, as the increase of one unit in GDP led to a decline in the annual growth rate of unemployment by 0.25 percent in the Palestinian territories as a whole, and to 2.05 percent in the West Bank and 0.31 percent in Gaza.

Yousefat (2011) carried out research on the Algerian economy during the period 1970 -2009 using the correlation matrix, casual and test, simultaneous integration methodology and error correction model. The findings revealed the existence of a slight \& inverse causal relationship of unemployment to economic growth and the lack of a long or shortterm balancing relationship between the rates of unemployment and economic growth, while the causality test has shown its results on the existence of a causal relationship in one direction from unemployment to the growth.

While Juda \& Esa (2010) were trying to estimate the Okun coefficient in the short \& long term in Iraq; the analysis results have shown that the unemployment rate is insensitive to change in the GDP, and the correlation coefficient is weaker between the two variables, due to the employment policy in Iraq, and thus it is inappropriate with its economic policies. Thus this law is inadequate for Iraq.

Al-Habees \& Abu Rumman (2012) studied this relationship in the Jordanian economy and some Arab countries. They have found that there is a very positive trend for the high growth rates and the relative decline in the unemployment rate, but that does not confirm the existence of a strong relationship between growth and unemployment. 
Kreishan (2011) has studied this relationship on the Jordanian economy for the period 1970-2008, using the techniques of time series analysis by using the co-integration test and Durban Watson (CRDW) method. He concluded that Okun's law is unreliable for Jordan as the lack of growth does not explain the problem of unemployment in Jordan.

In a study by Keller \& Nabil (2002) they indicated that the economic growth in MENA countries was not enough compared to the labour force in the region and high growth does not guarantee good results for the labour market.

\section{Experimental Methodology Results}

The aim of this study is to test the existence of a relationship between the unemployment rate and economic growth through the employment of Johansen co-integration method and Granger casual test upon quarterly data for Egypt covering the period between 2006: $\mathrm{Q}_{1}-2013: \mathrm{Q}_{2}$. This data has been compiled from different sources namely: General Authority for Investment and Free Zones, Central Agency for Public Mobilization and Statistics, (2005), and different numbers of reports of follow-up plan of economic and social development issued by the Ministry of Economic Development of Egypt and finally from the Monthly Bulletin of Statistics Online (MBS).
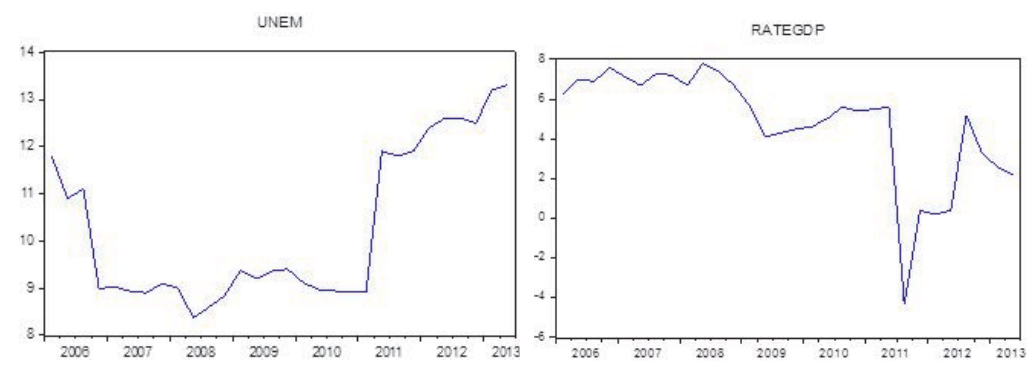

Figure 2: Diagram of Unemployment rate and GDP Rate

Sources: Central Agency for Public Mobilization and Statistics, Ministry of Economic Development of Egypt and United Nation (UN) Monthly Bulletin of Statistics Online (MBS), all data extracted from various years (2006-2013).

In Figure 2 the right hand side represents the unemployment rate series. It showed a downward trend at the beginning of 2006 and continued to drop to the lower rate at the second quarter of 2008, and then fluctuated between 8.6 percent and 8.9 percent until the first quarter of 2011, to take the upward direction.

On the left side of the figure, we can look at the behaviour of economic growth for the period under study, which has seen two economic crises, the first in 2008, which declined to 6.7 percent and 4.1 percent, and the second crisis after the $25^{\text {th }}$ January revolution, the subsequent disruption in macroeconomic indicators up to a point less than -4.3 percent at the third quarter of 2011.

\subsection{Preliminary testing: stationary test}

The first stage is the analysis of time series in order to obtain reliable results is not subject to spurious correlation to determine whether these series are stationary or non-stationary, to determine the rank of integration integrated order Kreishan (2011), by using the Unit Root Test. There are several tests, one of the most important and most commonly used in recent studies which can be relied upon in the unit root test is the test of augmented Dickey-Fuller (ADF), (Dickey-Fuller 1986, 1981, 1979). ADF test is based in the stationary study of variable series on the following models. Pinn et al (2011):

1. $\Delta y_{t}=\gamma y_{t-1}+\sum_{i=1}^{p} p_{i} \Delta y_{t-1}+\mu_{t}$

2. $\Delta y_{t}=\alpha_{0}+\gamma y_{t-1}+\sum_{j=1}^{p} p_{i} \Delta y_{t-1}+\mu_{t}$

3. $\Delta \mathrm{y}_{\mathrm{t}}=\alpha_{0}+\alpha_{2} \mathrm{t}+\gamma \mathrm{y}_{\mathrm{t}-1}+\sum_{j=1}^{p} p_{i} \Delta y_{t-1}+\mu_{t}$

The following hypotheses were tested:

Where: $\mathrm{y}_{\mathrm{t}}$ is the time series of interest, $\Delta$ is the first difference operator, $\Delta \mathrm{y}_{\mathrm{t}-1}=\left(\mathrm{y}_{\mathrm{t}-1}-\mathrm{y}_{\mathrm{t}-2}\right), \Delta \mathrm{y}_{\mathrm{t}-2}=\left(\mathrm{y}_{\mathrm{t}-2}-\mathrm{y}_{\mathrm{t}-3}\right)$ etc. $\gamma=(\rho-1)$ is the order of augmentation of the test, $t=$ linear trend, $\propto=$ constant intercept and $\mu_{t}$ is a white noise error term. The null hypothesis in this test is that the series are non stationary and contains unit root $(\gamma=0)$, while the alternative is that the series are stationary $(\gamma \neq 0)$ and there is no unit root. 
The estimation results show that the null hypothesis of unit root cannot be rejected at the 5 percent level of significance in the Dickey-Fuller (ADF) unit root test for I (0). Therefore, the results imply that the underlying variables after differentiation show a stationary process. All variables are stationary at first difference I (1). Table 2 shows the results:

Table 2: Results of Augmented Dickey Fuller Test

\begin{tabular}{|l|c|c|c|c|}
\hline \multirow{2}{*}{ Variable } & \multicolumn{4}{|c|}{ Level } \\
\cline { 2 - 5 } & Constant & Critical Value 5\% & None & Critical Value 5\% \\
\hline Rate of Economic Growth \% & -2.332 & 2.968 & -1.376 & -1.953 \\
\hline Unemployment Rate \% & -0684 & -2.968 & 0.268 & -1.953 \\
\hline \multirow{2}{*}{ Variable } & \multicolumn{4}{|c|}{ First Difference } \\
\cline { 2 - 5 } & Constant & Critical Value5\% & None & Critical Value 5\% \\
\hline Rate of Economic Growth \% & $-7.395^{*}$ & -2.972 & $-7.482^{*}$ & -1.953 \\
\hline Unemployment Rate \% & $-5.575^{*}$ & -2.972 & $-5.610^{*}$ & -1.953 \\
\hline $\begin{array}{l}\text { Significant values at 1\% ; 5\% } \\
\text { Time Trend Form was excluded from the estimation due to no existence of evidence thereon. }\end{array}$ \\
\hline
\end{tabular}

Having established that the two series are constant and of the same rank, we turn to the co-integration test to check for the existence of a relationship between the long-term economic growth and unemployment, and then test for Granger causality tests.

Both variables are Integrated for first difference I (1), we turn to Johansen co-integration test, which is considered even better if there are two variables only, because it allows the mutual impact among the variables under study, and it is supposed to be non-existent in the methodology (Engle-Granger) method of two-steps, as it is that it is more robust and performs better for small sample sizes. To determine the number of co-integration vectors (Johansen: 1988,1999; Johansen and Juselius :1990) suggest two statistical tests: first, the trace test, which tests the null hypothesis stipulated that the unique number of co-integration vectors is less or equal to the number $(q)$ versus the alternative hypothesis $(q=$ $1)$, and it is calculated according to the following formula:

$\lambda_{\text {trace }}(r)=-T \sum_{i=r+1}^{n} \ln \left(1-\hat{\lambda}_{r+1}\right)$

Whereas $\left(\lambda_{n}, \ldots \ldots . \lambda_{r+1}\right)$ represents the eigenvectors $(\mathrm{pr})$, and the null hypothesis indicates that the number of co-integration vectors is equal or less than (r) Abdali (2007). The second test is the maximal eigenvalue test; the test depends on the null hypothesis that there co-integration vector $(r)$ against the alternative hypothesis on existence of cointegration vector $(r+1)$; its statistics is calculated according to the following formula, Hussain et.al (2010):

\section{$\lambda_{\max }(r, r+1)=-T \ln \left(1-\hat{\lambda}_{r+1}\right)$}

However, before performing the co-integration test, we shall first determine the lags intervals because the results of co-integration tests are very sensitive to select the lag length. According to Vector Auto-regression "VAR" form is applied to data in order to find the appropriate lags intervals, Refer to Kabaklarliet.al (2011) and the Table 3 below.

Table 3: VAR Lag Order Selection Criteria VAR

\begin{tabular}{|c|c|c|c|c|c|c|}
\hline Lag & LogL & LR & FPE & AIC & SC & HQ \\
\hline 0 & -113.4523 & NA & 13.07760 & 8.246594 & 8.341752 & 8.275685 \\
\hline 1 & -87.74624 & 45.90372 & 2.778906 & 6.696160 & 6.981632 & 6.783432 \\
\hline 2 & -77.31725 & $17.13334^{*}$ & $1.766381^{*}$ & $6.236946^{*}$ & $6.712734^{*}$ & $6.382399^{*}$ \\
\hline
\end{tabular}

LR: sequential modified LR test statistic (each test at 5\% level) FPE: Final prediction error, AIC: Akaike information criterion, SC: Schwarz information criterion, HQ: Hannan-Quinn information criterion

According to the above table, five criteria are chosen appropriate lag which are (HQ-LR-FPD-AIC-SC) indicates *to be the best Lag chosen. Therefore, Lags 2 will be selected to estimate the Johansen co-integration test.

Tables 4 and 5 refer to the results of Johansen Method under Trace and maximal eigenvalue test on the rate of GDP and the unemployment rate for Egypt. Table 4 shows there is no co-integration as the trace stat value of first rank is not significant at 5 percent level. Whereas, Table 5 also shows the same results because maximum Eigen stat value is also insignificant at 5 percent level. All these results confirm that there does not exist a long run relationship among the variables. 
Table 4: Johansen Integration Test (Trace Eigenvalue Statistic)

\begin{tabular}{|c|c|c|c|c|}
\hline Hypothesized No. of CE (S) $^{*}$ & Eigenvalue $\pi$ & Trace Statistic & Critical Value 0.5 & Prob. \\
\hline None $^{*}$ & 0.278 & 9.059 & 12.321 & 0.166 \\
\hline At most $1^{*}$ & 0.009 & 0.237 & 4.129 & 0.685 \\
\hline
\end{tabular}

Note: $\left.{ }^{* * *}\right)$ denotes rejection of the hypothesis at the $5 \%(1 \%)$ level.

Table 5: Johansen Integration Test (Maximum Eigenvalue Statistic)

\begin{tabular}{|c|c|c|c|l|}
\hline Hypothesized No. of CE (S) & Eigenvalue $\pi$ & Max- Eigen Statistic & Critical Value 0.5 & Prob. \\
\hline None $^{*}$ & 0.279 & 8.822 & 11.225 & 0.128 \\
\hline At most 1 & 0.009 & 0.237 & 4.129 & 0.684 \\
\hline
\end{tabular}

Note: $\left.{ }^{*}{ }^{*}\right)$ denotes rejection of the hypothesis at the $5 \%(1 \%)$ level.

Determination of the causality between economic variables identifies the type of relationship between these variables in the short term, which gives us a good understanding of economic phenomena. It could be argued that the variable $(X)$ causes $(Y)$ if the predicted $(Y)$, which relies heavily on the past two variables $(Y, X)$ is better than the predicted $Y$, which depends only on the past of $Y$, Shibi \& Btahir (2010). In order to identify the direction of causality between variables, Granger Causality test is applied.

Casualty test from $(X)$ to $(Y)$ is according to the following equation, Hijazi (2010):

$Y=\propto_{0}+\sum_{i=1}^{m} \propto_{1 i} Y_{t-1}+\sum_{i=1}^{n} \propto_{2 i} X_{t-1}+\varepsilon_{t}$

While the causality vector test is done from $(Y)$ to $(X)$ by using the following equation:

$X=\propto_{0}+\sum_{i=1}^{h} \propto_{1 i} X_{t-1}+\sum_{i=1}^{k} \propto_{2 i} Y_{t-1}+\varepsilon_{t}$

The presence or non presence of causality relationship is tested by using the estimated $F$ statistics, to be compared with $\mathrm{F}$ statistics at a determined significant level, where the hypothesis under testing is the lack of a relationship.The results of Granger causality are contained in table 6 . The results revealed there is a unidirectional causality relationship from the unemployment rate to economic growth in Egypt. The F-statistics valueis significant at 5 percent.

Table 6: Illustrates Results of Granger Causality Test between GDP \& Unemployment Rate

\begin{tabular}{|l|c|}
\hline Null Hypothesis & Calculated FISHER Statistic \\
\hline Unemployment not caused to Economic Growth & $15.184^{*}$ \\
\hline Economic Growth not caused to Unemployment & 0.953 \\
\hline
\end{tabular}

\section{Conclusion}

This paper assessed the relationship between growth and unemployment in Egypt between $2006 \mathrm{Q}_{1}-2013 \mathrm{Q}_{2}$. To assess this relationship, the Dickey-Fuller (ADF) unit root test, the Johansen Co-integration test and the Standard Granger Causality test were applied to observe the relationship between unemployment and Gross Domestic Product (GDP). The results indicated there were no co-integration relationship between the variables of unemployment and GDP specifically implying there is no long-term relationship between the variables. However, in the short term, there is a direct causality relationship have been observed between the unemployment rate to economic growth. The experimental results of this study confirm that there is no relationship between economic growth and unemployment in the Egyptian economy.

Uniquely about Egyptian economy is that, although growth rates are positive in some periods, but it was unable to significantly reduce the unemployment rate. The main reason is due to the nature of the Egyptian economy as it depends on capital-intensity rather than labour intensity. It results in lower contribution to the reduction of unemployment rates. This result is consistent with the other studies in the Arab countries as mention in the previous literatures. Thus, continuous efforts in creating job opportunities (either from government or private sectors) should be implemented significantly to reduce unemployment problems as the high growth in Egypt is not a significant sign of bursting employment. Increasing the employment rate requires policies to promote activities and sectors which have large labour content such as services, construction, and agriculture. 


\section{References}

Abdali, Abed. (2007). Determinants of demand for imports of Saudi Arabia in the framework of co-integration and error correction.Magazine of SalehKamel Centre for Islamic Economy, Al-Azhar University, Nr. 32. 20-65

Abdelmawla, M. M. (2012). Report about follow-up the performance of the Egyptian economy. Development partners for research, consulting, training, follow-up report of monthly performance

Al-Eid, Sheikh Jalal.Bahdi, Esa. (2012). Measure the impact of economic growth on the unemployment rate in the Palestinian territories For the period 1996 -2011 Researcher Magazine No, 11, 23-34.

Al-Ghannam, H. A. (2003). The relation between economic growth and employment in Saudi private firms. Saudi Economic Association, economic studies, volume(5, 9).KingSaud University.

Al-Habees, Mahmoud A.\& Abu Rumman,Mohammed(2012).The Relationship between Unemployment and Economic Growth in Jordan and Some Arab Countries. World Applied Sciences Journal18 (5): 673-680.

Annual growth rate of GDP at local market prices; issue from the following site on 04/12/2013 at 1:50 p.m. http://data.worldbank.org /indicator

Chloe, Arne. (2012). Impact of the economic crisis on trade and foreign investment and employment in Egypt. American Chamber of Commerce in Egypt, February http://www.ilo.org/public/english/region/afpro/cairo/downloads/trade_arabic.pdf

Dahmani, Driouche.(2013)" Economic Growth and Unemployment in Algeria: An Econometric Study".Journal Najah University for Research (Humanities). Volume 27, Issue (6).

Development of performance indicators for Egyptian economy (2013).General Authority forlnvestment and Free Zones, in various periods 2013, issue from the site: http://www.gafi.gov.eg/content/AR/macro/Macro Arabic June 2013.pdf

Different numbers of reports of follow-up economic and social development, Ministry of Economic Development, Arab Republic of Egypt, from the site: http://www.mop.gov.eg/MOP/followUpRep.aspx?ModID=2

Harris, R \& Silverstone, B. (2001).Testing for asymmetry in Okun's law: A cross-country comparison.Economics Bulletin. Vol. 5. No. (2)

Hijazi, Azza. (2010). Characteristics of economic fluctuations in Egypt.Journal of Development and Economic Policy - first issue, 9-35.

Hussain, T. Siddiqi, M. W \& Iqbal, A. (2010) .A Coherent Relationship between Economic Growth and Unemployment: An Empirical Evidence from Pakistan.International Journal of Human and Social Sciences 5:5.

Ivan Kitov\& Oleg Kitov (undated) .Employment, unemployment and real economic growth. Retrieved from http://arxiv.org/ftp/arxiv/ papers/1109/1109.4399.pdf

Juda, N. H. \& Esa, R. A. (2010).Relationship between economic growth and unemployment in Iraq using Okun's law and TodaYamamoto test.Al-Qadissia Journal of Administrative \& Economic Sciences, Volume 12, Issue (3), 63-87.

Kabaklarli, Esra. Perihan, Hazel Er. \& Buluş, Abdül Kadir. (2011).Economic Determinants of Turkish youth Unemployment Problem: Cointegration Analysis. International Conference on Applied Economics - ICOAE.

Keller, J. \& Nabil, M.K. (2002). The Macroeconomics of Labor Market Outcomes in MENA over the 1990s: How Growth has failed to keep Pace with a Burgeoning Lab our Market. Working Study, the Egyptian Center for Economic Studies.

Kreishan, Fuad M. (2011). Economic Growth and Unemployment: An Empirical Analysis. Journal of Social Sciences 7 (2): $228-231$.

Lee, J. (2000). The Robustness of Okun's law: Evidence from OECD countries. Spring 2000 J. Macroeconomics. Vol. 22, No. 2, 331 356

Mahfouz, Aladdin Morgan.(2009). Global financial crisis and its impact on Egyptian economy.Ministry of Commerce and Industry, sector of SME Export Development - extracted from: http://www.mfti.gov.eg/SME/pdf/researchs/3.pdf

Mahrous, Lamia Saeed. (2005). Survey of most important studies of the macroeconomic models applied to the Egyptian economy during the period (1971-2004). The Council of Ministers, Center for Information and Decision Support; Economic analysis sector in July.

Ministry of Investment (2012), "Evolution of the Egyptian economy performance indicators", February http://www.investment.gov.eg/ ar/Economiclndicators/Documents/MacroeconomicIndicators2010-A.pdf

Moosa, Imad A. (2008). "Economic Growth and Unemployment in Arab Countries: Is Okun's law valid?". International conference on "the unemployment crisis in the arab countries".17-18 march 2008.cairo- Egypt.

Nabil Haney, Mohamed \& Zuhair, Graah. (2012). "Test the random progress model for the movement of stock prices in the context of the efficiency of financial markets in the emerging Arab stock markets - Case Study: Stock Exchange of Morocco and Kuwait". Economic and administrative researches - Mohamed Khider University of Biskra - Faculty of economic, trade and managerial sciences, Nr. 11.49-87.

Pinn, S. L. S., Ching, K. S., Kogid, M., Mulok, D., Mansur, K., \& Loganathan, N. (2011). Empirical analysis of employment and foreign direct investment in malaysia: An ARDL bounds testing approach to cointegration. Advances in Management and Applied Economics, 1(3), 77-91

Revenge, Ana L. \& Bentolia, Samuel. (1995). What Affects the Employment Rate Intensity of Growth? Bancodo Espana, Working Paper, 9517. Extracted from: http://www.bde.es/f/webbde/SES/Secciones/Publicaciones/PublicacionesSeriadas/DocumentosTrabajo/ 95/Fich/dt9517e.pdf

Shibi, Abdurrahim. \& Btahir, Samir. (2010) .Effectiveness of fiscal policy in Algeria: Analytical \& standard approach, Journal of Development and Economic Policy, Volume XII - the first issue - January. 38-59

Shorbaji, Majdi.(2009). Impact of economic growth on employment in the Egyptian economy. Magazine of North Africa Economies, No. 6) Algeria. 141-170.

Sogner, L. \& Stiassny,A. (2002). An analysis on the structural stability of okun's law--A cross- Study country.Applied Economics, 14, $1775 \pm 1787$ 
Statistical Yearbook. (2005). Central Agency for Public Mobilization and Statistics, Egypt; issue from the site: http://www.capmas.gov.eg /pdf/book_years/2005.pdf

Unemployment rate of the total workforce; issue from the following site on 04/12/2013 at 1:55 p.m. http://data.worldbank.org/indicator

United Nations (UN), Monthly Buletin of Statistics Online (MBS), extracted on 25/10/2013 from: http://unstats.un.org/unsd/mbs/ app/DataSearchTable.aspx

Yerdelen, Ferda. (2011).Thelong and short run effects between unemployment and economic growth in Europe. Doğuş Üniversitesi Dergisi, 12, 1, 99-113

Yousefat, Ali. (2011). Unemployment and economic growth in Algeria in the periods from 1970 to 2009. International Forum on: Government's strategy to eliminate the unemployment and achieve the sustainable development on: 15-16 November 2011, AlMsila University, Algeria.

Zagler, M. (2003). A vecter error correction model of economic growth and unemployment in major European countries and an analysis of Okun's law. Applied Econometrics and International Development. AEEADE. Vol. 3 -3

Table 1: Unit Root Test

Null Hypothesis: rate UNEMP has a unit root

Exogenous: None

Lag Length: 0 (Automatic - based on SIC, maxlag=7)

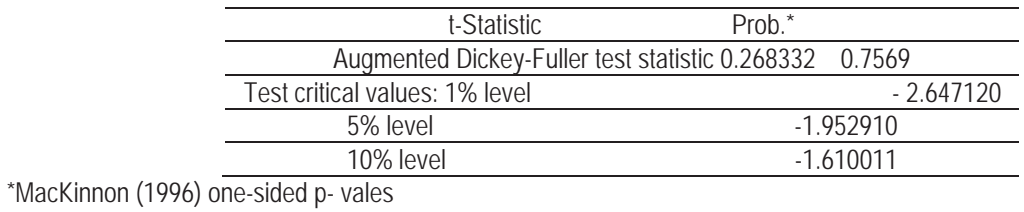

Null Hypothesis(rate UNEMP) has a unit root

Exogenous: None

Lag Length: O(Automatic- based on SIC, maxlag =7)

\begin{tabular}{|c|c|c|}
\hline t-Statistic & \multicolumn{2}{|c|}{ Prob.* } \\
\hline Augmented Dickey-Fuller test statistic & -5.610199 & 0.0000 \\
\hline Test critical values: $1 \%$ level & & -2.650145 \\
\hline $5 \%$ level & & -1.953381 \\
\hline $10 \%$ level & & -1.609798 \\
\hline
\end{tabular}

Null Hypothesis: rate GDP has a unit root

Exogenous: None

Lag Length: 0 (Automatic - based on SIC, maxlag=7)

\begin{tabular}{ccc}
\hline \multicolumn{2}{c}{ t-Statistic } & Prob. $^{*}$ \\
\hline Augmented Dickey-Fuller test statistic & -1.376250 & 0.1531 \\
\hline Test critical values: 1\% level & -2.647120 \\
\hline 5\% level & -1.952910 \\
\hline $10 \%$ level & -1.610011 \\
\hline
\end{tabular}

*MacKinnon (1996) one-sided p- vales

Null Hypothesis: D(rate GDP) has a unit root

Exogenous: None

Lag Length: 0 (Automatic - based on SIC, maxlag=7)

\begin{tabular}{ccc}
\hline \multicolumn{2}{c}{ t-Statistic } & \multicolumn{2}{c}{ Prob. $^{*}$} \\
\hline Augmented Dickey-Fuller test statistic & -7.481575 & 0.0000 \\
\hline Test critical values: 1\% level & -2.650145 \\
\hline $5 \%$ level & -1.953381 \\
\hline $10 \%$ level & -1.610979 \\
\hline
\end{tabular}

*MacKinnon (1996) one-sided p- vales 


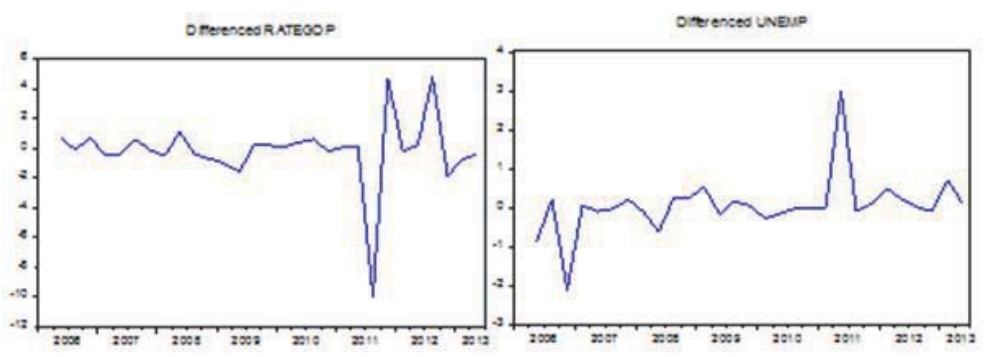

Table 2: Cointegration Test

Included observations:27 after adjustments

Trend assumption: No deterministic trend

Series: rate UNEMP rate GDP

Lags interval (in first differences): 1 to 2

\section{Unrestricted Conintegration Rank Test (Trace)}

\begin{tabular}{|c|c|c|c|c|c|}
\hline Hypothesized & Eigenvalue & Trace & 0.05 & & prob $^{* *}$ \\
\hline No. of $\mathrm{CE}(\mathrm{s})$ & & & statistic & critical value & \\
\hline None & 0.278731 & 9.05926 & 12.32090 & & 0.1656 \\
\hline At most 1 & 0.008746 & 0.23718 & 4.129909 & & 0.6846 \\
\hline
\end{tabular}

Trace test indicates no cointegration at $5 \%$ level

* denotes rejection of the hypothesis at the $5 \%$ level

** Mackinnon-Haug-Michelis(1999) p-values

\section{Unrestricted Cointegration Rank Tank Test(Maximum Eigenvalue)}

\begin{tabular}{|c|c|c|c|c|}
\hline \multirow{3}{*}{$\begin{array}{l}\text { Hypothesized } \\
\text { No. of CE(s) } \\
\text { None }\end{array}$} & \multirow{2}{*}{ Eigenvalue } & \multirow[t]{2}{*}{ Max- Eigen } & \multirow[b]{2}{*}{ statistic } & \multirow[t]{2}{*}{ prob $^{\text {** }}$} \\
\hline & & & & \\
\hline & 0.278731 & 8.822077 & 11.22480 & 0.1284 \\
\hline At most 1 & 0.008746 & 0.237189 & 4.129906 & 0.6846 \\
\hline
\end{tabular}

Max- Eigenvalue test indicates no cointegration at 5\% level

* denotes rejection of the hypothesis at the $5 \%$ level

** Mackinnon-Haug-Michelis(1999) p-values

Table 3: Causality Tests

Pairwise Granger Causality Tests

Sample: $2006 \mathrm{Q}_{1} 2013 \mathrm{Q}_{2}$

lags: 2

\begin{tabular}{lccc}
\hline Null Hypothesis: & Obs & F-Statistic & prob \\
\hline UNEMP does not Granger Cause GDP & 28 & 15.1840 & $6 . \mathrm{E}-05$ \\
\hline GDP does not Granger Cause UNEMP & & 0.95318 & 0.4002 \\
\hline
\end{tabular}

